\title{
Ripening and Physiological Changes in the Fruit of Persea schiedeana Nees during the Postharvest Period
}

\author{
Oscar Andrés Del Angel-Coronel \\ Instituto Tecnológico Superior de Huatusco, Avenida 25 Poniente No. 100, \\ Col. Reserva Territorial, Huatusco, Veracruz 94100, México
}

Juan Guillermo Cruz-Castillo ${ }^{1}$

Univ. Autónoma Chapingo, Centros Regionales-CRUO, Km 6. Carr. Huatusco-Xalapa, Huatusco, Veracruz 94100, Mexico

Javier De La Cruz-Medina

Unidad de Investigación y Desarrollo en Alimentos, Instituto Tecnológico de Veracruz, Avenida Miguel Ángel de Quevedo No. 2779, Veracruz 91860 , Mexico

\section{Franco Famiani \\ Dipartimento di Scienze Agrarie e Ambientali, Università degli Studi di Perugia, Borgo XX Giugno 74, 06121 Perugia, Italy}

Additional index words. Mesoamerican fruit, climacteric fruit, perishable fruit, neglected fruit, postharvest physiology

\begin{abstract}
In terms of color, firmness, respiration, and ethylene production during the postharvest period, ripening is here characterized for the first time in the fruit of Persea schiedeana Nees. The results show a respiratory peak (respiratory climacteric) and an ethylene production peak, indicating that the fruit of $\boldsymbol{P}$. schiedeana can be classified as climacteric. The fruit ripened rapidly, and senescence effects appeared 5 days after harvest. Together with appreciable weight loss during the postharvest period, this makes the fruit very perishable. Preliminary values for quantitative ripening indices are provided (fruit firmness, color lightness, hue angle, and chroma).
\end{abstract}

Persea schiedeana Nees. is a fruit tree species belonging to the Lauraceae family that is found from the central part of Mexico to Panama (Munsell et al., 1950). The trees grow wild in the mesophile forests, and the fruit is a drupe that is eaten by mammals (Gallina et al., 1996). P. schiedeana is sometimes used to produce shade in coffee (Coffea arabica L.) plantations.

In the Mesoamerican region, i.e., southern Mexico, Guatemala, El Salvador, Honduras, and Belice, the pulp of the P. schiedeana fruit is a popular food. When the fruit is mature, the pulp is spread on corn (Zea mays L.) tortillas and eaten as a "taco," and in Guatemala, the mesocarp is also used in black bean soup. This fruit is mainly sold in regional markets and rarely appears in supermarket chains, also because it has a short postharvest life, which limits its marketability.

$P$. schiedeana has not been cultivated on a large scale in orchards (as a monoculture) for fruit production, but it is generally cultivated in home gardens. No cultivars have been selected for the production of fruit for

Received for publication 16 July 2009. Accepted for publication 16 Nov. 2009.

${ }^{1}$ To whom reprint requests should be addressed; e-mail jcruzcastillo@yahoo.com. human consumption. $P$. schiedeana has also been used as a rootstock for avocado because it can tolerate attacks of Phytophthora cinnamomi Rands to the root system (Zentmayer et al., 1988).

The fruit of $P$. schiedeana is called chinín or chinene in Mexico; chucte, chupte, or coyou in Guatemala; and shucte or sucte in Honduras.

The few studies that have been conducted on the fruit of $P$. schiedeana have investigated its mineral content (Munsell et al., 1950), morphology (length and diameter, skin and pulp color), weight, and composition in terms of dry matter, fiber, and oil (Cruz-Castillo et al., 2007; Joaquín-Martínez et al., 2007). The physical and chemical characteristics of the oil and its fatty acid composition have also been evaluated (CruzCastillo et al., 2007; Joaquín-Martínez et al., 2007; Rendón-Cantillano, 2003). The dimensions and weight of the fruit vary greatly, ranging from $100 \mathrm{~g}$ to $450 \mathrm{~g}$ (Cruz-Castillo et al., 2007; Joaquín-Martínez et al., 2007). Different lines of $P$. schiedeana can be distinguished according to the skin color of the fruit (Joaquín-Martínez et al., 2007), which can be black, green, dark red, orange, or greenish yellow. The oil content ranges from $25 \%$ to $36 \%$ of the fruit fresh weight (Joaquín-Martínez et al., 2007). This oil content is much higher than the $4 \%$ to $7 \%$ oil in the mesocarp of West Indian avocados (Biale and Young, 1971), which are grown in areas where $P$. schiedeana is also found. These values are also higher than those reported for high oil-containing avocado varieties (Gómez-López, 2002) and are similar, higher, or much higher than those reported for the fruit of olive cultivars (Lavee, 1996). The fatty acid composition of the oil is quite variable. The oleic acid content ranges from $37 \%$ to $60 \%$; this represents the main fatty acid and it is very important from a nutritional point of view (Cruz-Castillo et al., 2007; Joaquín-Martínez et al., 2007; Rendón-Cantillano, 2003). Genotypes that have fruit with high oil and oleic acid contents are potentially a source for oil that could be extracted and used in the human diet. Because this fruit is used as food and could be used to extract oil, $P$. schiedeana is of interest as a possible special crop. For this, the best genotypes need to be selected.

The fruit is harvested according to the number of days after fruit set (Cruz-Castillo et al., 2007) and the color and the firmness of the fruit evaluated by sight and squeezing the fruit with the hands. No quantitative (instrumental) color and firmness data are available that can be used as reference points to determine when to harvest. The ripeness for the fruit to be eaten is evident from the fruit firmness and color (pale green for greencolored fruit); again, no quantitative reference data are available as a measure of eating ripeness.

The present study has investigated the fruit characteristics (color and firmness) at the time of harvesting and during the postharvest ripening as well as the physiological processes related to ripening such as respiration and ethylene production. The results obtained allow initial characterization of the ripening process of the $P$. schiedeana fruit, provide a better understanding of its physiology, and are useful to improve its postharvest management.

\section{Materials and Methods}

Tree characteristics and location and fruit sample collection. Fruits of $P$. schiedeana $(\mathrm{n}=72)$ were harvested from the south side of the canopy of three trees (24 fruits/ tree) that produced green-skinned fruit. The trees were $\approx 30$ years old and $18 \mathrm{~m}$ high and were located in Huatusco, Veracruz, México (long. $19^{\circ} 10^{\prime} 24^{\prime \prime} \mathrm{N}$, lat. $96^{\circ} 57^{\prime} 45.6^{\prime \prime} \mathrm{W}$ ) at an altitude of $1300 \mathrm{~m}$ a.s.1. The fruits were harvested in mid-July based on the number of days after the fruit set $(\approx 90$ d) (Cruz-Castillo et al., 2007), the pale green color of the skin (evaluated by sight), and the firmness (evaluated by squeezing the fruits with the hands) (Fig. 1).

Postharvest conditions. The fruits from the three trees were mixed for all of the analyses and kept at room temperature (25 $\pm 2{ }^{\circ} \mathrm{C}$ ) at a relative humidity of $80 \%$ to $85 \%$. 
Fruit measurements. The fruit firmness and color were evaluated at harvest and at 2-d intervals during the postharvest period. The firmness was measured by penetrating the skin and the mesocarp with a handheld penetrometer (Effegi, Ravenna, Italy), with a 4-mm-diameter plunger, and expressed in Newtons; the mean of two equatorial measurements per fruit was considered as one replication. Skin and mesocarp color were measured at three different equidistant points around the equatorial area of the fruit using a colorimeter (Miniscan XE Plus; HunterLab, Reston, VA); the mean of the three measurements was considered as one replication. The lightness $\left(\mathrm{L}^{*}\right)$, hue angle $(\mathrm{h})$, and chroma $\left(\mathrm{C}^{*}\right)$ values are reported according to MacGuire (1992). The fruit weight loss during the postharvest period was determined by weighing the fruits daily and was expressed as a percentage of the initial weight at harvest.

Fruit respiration and ethylene production measurements. Gas chromatography was used to determine the $\mathrm{CO}_{2}$ evolution and $\mathrm{C}_{2} \mathrm{H}_{4}$ production. A 5890 -Series II gas chromatograph was used (Hewlett Packard, Ramsey, NJ) fitted with a $15 \mathrm{~m} \times 0.25-\mathrm{mm}$ Porapak-Q column. Ethylene production was measured using a flame ionization detector, and $\mathrm{CO}_{2}$ was determined with a thermal conductivity detector. The oven, injector, and detector temperatures were 100, 150, and $250{ }^{\circ} \mathrm{C}$, respectively. Every $24 \mathrm{~h}$, single fruits were put into 1-L airtight glass containers for $1.5 \mathrm{~h}$ with a septum for sampling. One milliliter of the headspace gas was withdrawn and injected into the chromatograph to determine the ethylene production $\left(\mu \mathrm{L} \mathrm{C}_{2} \mathrm{H}_{4} / \mathrm{kg} \cdot \mathrm{h}^{-1}\right)$ and respiration $\left(\mathrm{mL} \mathrm{CO} \mathrm{CO}_{2} /\right.$ $\mathrm{kg} \cdot \mathrm{h}^{-1}$ ) rates. The same column and chromatographic conditions were used for the $\mathrm{C}_{2} \mathrm{H}_{4}$ and $\mathrm{CO}_{2}$ analyses. $\mathrm{CO}_{2}$ at $99 \%$ and $300 \mu \mathrm{L} \cdot \mathrm{L}^{-1} \mathrm{C}_{2} \mathrm{H}_{4}$.were used as standards to calculate the amounts of these gases released by the fruit. All of the calculations to determine these two gases were according to the method of Saltveit and Yang (1987); they consider the volume of the chamber and the volume and fresh weight of the fruit.

Sequence used for fruit analysis and data handling. At the harvest and during the postharvest period considered, the same samples of fruit were used for all of the measurements. The nondestructive measurements

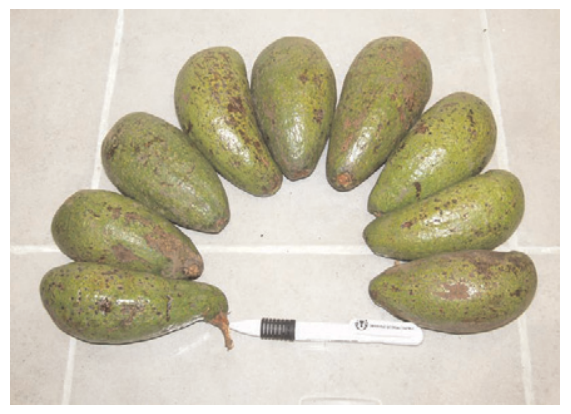

Fig. 1. Green-skinned P. shiedeana fruits used for the study. The scarring of the fruits resulted from preharvest insect damage. were determined first (weight, respiration, ethylene production, and skin color), and then the same fruits were used for the destructive measurements (fruit firmness and mesocarp color). For all of the measurements, nine fruits were chosen randomly with each considered as an experimental unit (replication). Experimental data are reported as means \pm SE.

\section{Results and Discussion}

Characterization of fruit ripening at harvest and during the postharvest period. At harvest, the mean fruit weight according to all of the harvested fruit was $180 \pm 7.2 \mathrm{~g}$. The mean fruit mesocarp and skin color values were, respectively, $\approx 100$ and 87 for hue angle, $40 \mathrm{~L}$ and $85 \mathrm{~L}$ for lightness, and 23 and 25 for chroma corresponding to a bright greenish yellow skin color and a bright yellow pulp (Fig. 2). The mean fruit firmness value was $\approx 31 \mathrm{~N}$ (Fig. 2). All of these parameters changed significantly during the postharvest period. The mean color purity (chroma), lightness $(\% \mathrm{~L})$, and hue values decreased slightly for up to $3 \mathrm{~d}$ (lightness and hue angle of skin) and $5 \mathrm{~d}$ (lightness and hue angle of mesocarp and chroma of both skin and mesocarp) after harvest, after which they decreased sharply. The skin remained greenish yellow up to $5 \mathrm{~d}$ after harvest and then became dark brown very quickly; the mesocarp became yellowish to slightly orange $3 \mathrm{~d}$ after harvest and yellowish brown $5 \mathrm{~d}$ after harvest and then it turned brown.

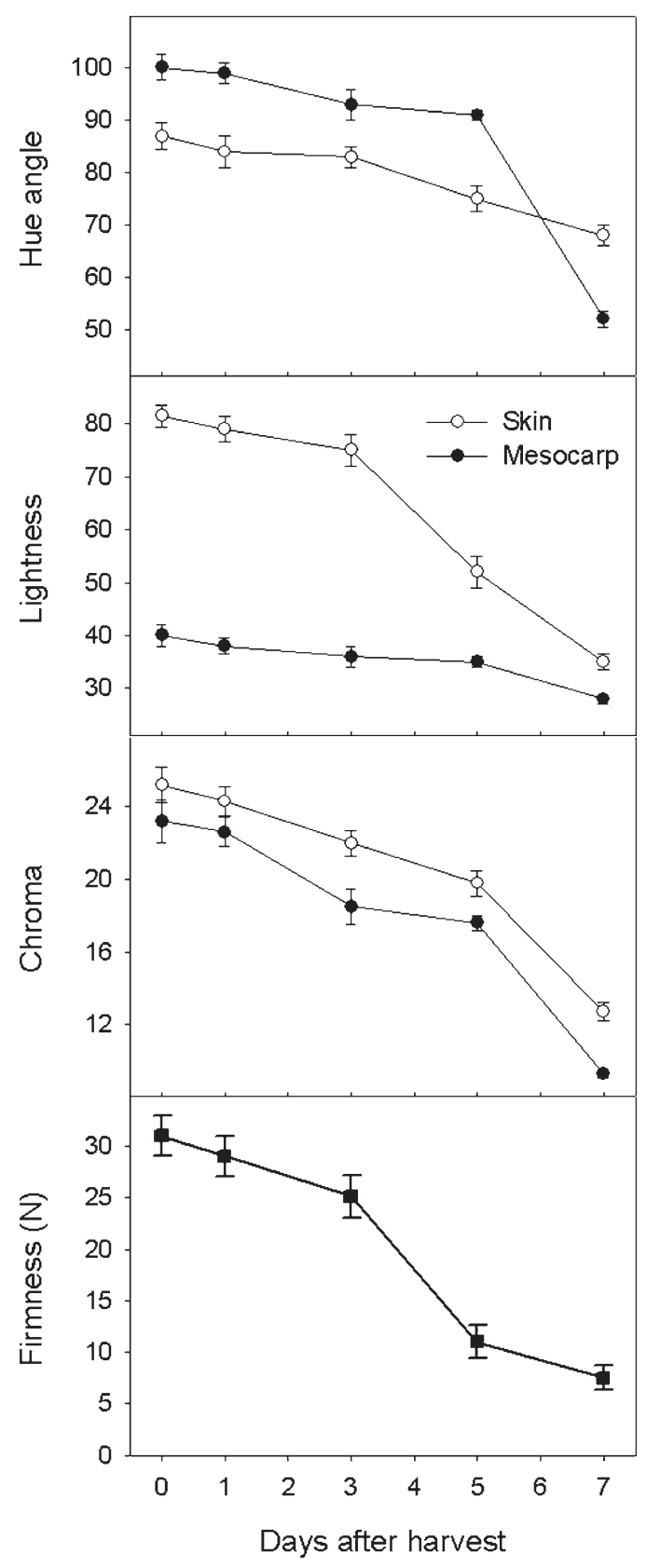

Fig. 2. Firmness and skin and mesocarp color of $P$. schiedeana fruits during ripening at $25^{\circ} \mathrm{C}$ and $80 \%$ to $85 \%$ relative humidity. Each point is the mean of nine replicates \pm se. 
The fruit firmness decreased gradually for up to $3 \mathrm{~d}$ after harvest, when it reached values of $\approx 23 \mathrm{~N}$ and then declined sharply (Fig. 2).

The fruit is ready for consumption when the skin is green-yellow and the mesocarp is yellow-orange, i.e., between 3 and $5 \mathrm{~d}$ after harvest, at a room temperature of $25^{\circ} \mathrm{C}$ and a relative humidity of $80 \%$ to $85 \%$. The intense browning of both the skin and the pulp in the last part of the considered postharvest period (5 to $7 \mathrm{~d}$ after harvest) indicated a rapid senescence of the fruit in this period of time.

During the postharvest period, the fruit showed an intense and constant loss for fresh weight; after $7 \mathrm{~d}$, this decrease in fresh weight reached $\approx 28 \%$ of the initial weight (a mean loss of $3.8 \%$ /day) (Fig. 3). A similar weight loss has been seen for other tropical fruits such as litchi (Litchi chinensis Sonn) (Jiang and $\mathrm{Fu}, 1999$ ). However, the weight loss in the present study was much higher than that of fruit belonging to the same genus such as avocado (Persea americana Mill.) (Ahmed et al., 2007; Cutting and Wolstenholme, 1991; Dixon et al., 2004), for which most of the weight loss was reported to be the result of water loss (Cutting and Wolstenholme, 1991). When this intense fresh weight loss is considered along with the rapid ripening and early appearance of senescence, these indicate that the fruit of $P$. schiedeana is highly perishable.

Physiological changes during ripening. Both fruit respiration and ethylene production reached a peak $3 \mathrm{~d}$ after harvest and then declined (Fig. 4). The respiratory and ethylene peaks of $P$. schiedeana $\left(550 \mathrm{~mL} \mathrm{CO}_{2} /\right.$ $\mathrm{kg} \cdot \mathrm{h}^{-1}$ and $880 \mu \mathrm{L} \mathrm{C} \mathrm{C}_{2} \mathrm{H}_{4} / \mathrm{kg} \cdot \mathrm{h}^{-1}$, respectively) were at least threefold and ninefold higher, respectively, than those reported for avocados (Kader and Arpaia, 2009) and also higher than those reported for soursop (Annona muricata L.), a highly perishable climacteric fruit $\left(250 \mathrm{~mL} \mathrm{CO} / \mathrm{kg} \cdot \mathrm{h}^{-1}\right.$ and $100 \mu \mathrm{L} \mathrm{C}_{2} \mathrm{H}_{4} /$ $\mathrm{kg} \cdot \mathrm{h}^{-1}$ ) (Bruinsma and Paull, 1984). It is important to note that the respiration intensity of the $P$. schiedeana fruit was relatively high before and after the observed peak, indicating that the fruit has a relatively intense basal metabolism.

Fruit can be classified as either climacteric or nonclimateric based on the respiration pattern and autocatalytic ethylene production during ripening. Climateric fruits show a respiratory burst (termed the respiratory climacteric) and pronounced ethylene synthesis during ripening, whereas nonclimateric fruits do not show such increases (Kader, 2002; Tucker, 1993). In climacteric fruits, the peak can correspond to optimum eating ripeness or it can precede or follow this depending on the fruit considered (Tucker, 1993). In a few cases, contrasting results have been reported regarding the occurrence of the respiratory climacteric. In melon and tomato, it has been reported that the respiratory climacteric might be an artifact of harvest (because the climacteric rise was only seen in the detached fruit and not in the still attached ones) and not a natural phenomena associated with ripening
(Saltveit, 1993; Shellie and Saltveit, 1993). In a successive study on melon, the respiratory climacteric was observed in fruit ripened both on and off the plant (Hadfield et al., 1995). These authors suggested that the respiratory behavior during ripening could also be cultivar-dependent (Hadfield et al., 1995). However, when the respiratory climacteric occurs with either detached or still attached fruit, it always indicates a turning point in terms of fruit ripening and senescence, and so it is always important to establish when this happens.

The respiration and ethylene production patterns of $P$. schiedeana fruit are those of a climacteric fruit. The respiration and ethylene production peaks corresponded to or slightly preceded the optimum eating ripeness (between the third and fifth days after harvest). The high perishability of $P$. schiedeana fruit is in agreement with the observation that fruit with high respiratory rates tend to ripen very rapidly and hence are the most perishable (Tucker, 1993). The high respiratory rates measured in the fruit of $P$. schiedeana can account for the high fruit weight loss observed during the postharvest period, because they might be responsible for a significant loss of dry matter in addition to that of water. Indeed, on a per-day basis ( $24 \mathrm{~h}$ ), the minimum and maximum respiration rates measured $\left(130\right.$ and $550 \mathrm{~mL} \mathrm{CO} / \mathrm{kg} \cdot \mathrm{h}^{-1}$, respectively) corresponded to a loss of $1.5 \mathrm{~g}$ and $6.5 \mathrm{~g}$ carbon $(\mathrm{C}) / \mathrm{kg}$, respectively. Considering that a common $\mathrm{C}$ content in plant tissue can be estimated to account for $\approx 30 \%$ to $35 \%$ of the dry matter, the amount of C lost through respiration corresponded to a loss of dry matter of $\approx 4.6 \mathrm{~g} \cdot \mathrm{kg}^{-1}$ and $20 \mathrm{~g} \cdot \mathrm{kg}^{-1}$ (i.e., a daily loss of fruit weight of $\approx 0.5 \%$ and $2 \%$, respectively).

\section{Conclusions}

The results of the present study indicate that the respiratory climacteric occurs in the

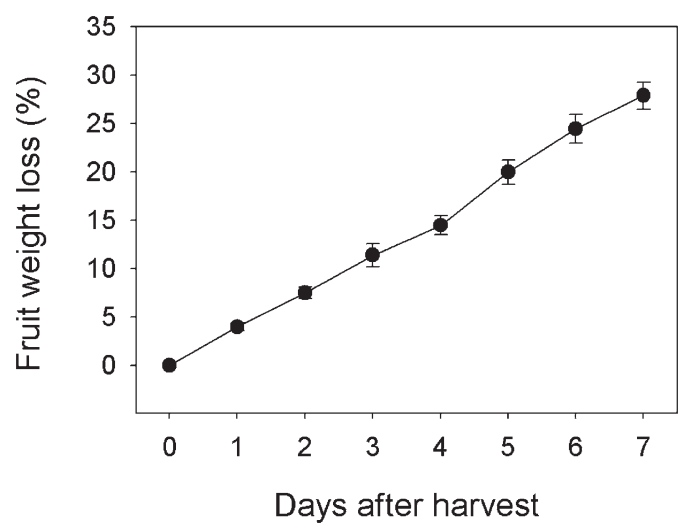

Fig. 3. Weight loss of $P$. shiedeana fruits during ripening at $25^{\circ} \mathrm{C}$ and $80 \%$ to $85 \%$ relative humidity. Each point is the mean of nine replicates $\pm \mathrm{SE}$.

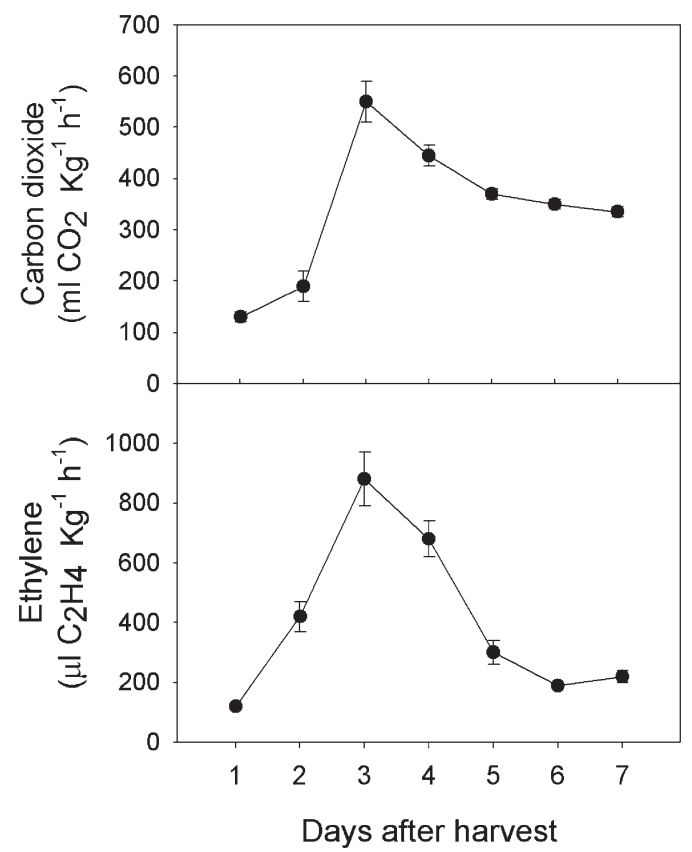

Fig. 4. Respiration and ethylene production of $P$. schiedeana fruits during ripening at $25{ }^{\circ} \mathrm{C}$ and $80 \%$ to $85 \%$ relative humidity. Each point is the mean of nine replicates $\pm \mathrm{SE}$. 
ripening fruit of $P$. schiedeana, and so this fruit should be classified among the climacteric group.

During the postharvest period, the $P$. schiedeana fruit ripens and senescences rapidly with an intense weight loss, resulting in a very perishable fruit. Preliminary indications for the quantitative ripening index values (fruit firmness, color lightness, hue angle, and chroma) are provided here for these green-skinned fruits. The very short time interval between harvest and the occurrence of the respiratory climacteric clearly indicate that if refrigeration (under normal or modified atmosphere) is applied to prolong the postharvest life of the P. schiedeana fruits, they should be placed under these conditions immediately after harvest so as to delay the climacteric rise.

Considering the high genetic variability of the $P$. schiedeana species, further studies are required to provide a more complete picture of what occurs at ripening and for the related physiological aspects. Moreover, it would be useful to integrate the initial results on fruit ripening obtained in the present study with additional investigations that also take into consideration different harvesting times and different postharvest temperature and relative humidity treatments.

\section{Literature Cited}

Ahmed, D.M., F.M. Ahmed, A. El-Mongy, B. AbuAziz, and A.R. Yousef. 2007. Postharvest storage of Hass and Fuerte avocados under modified atmosphere conditions. J. Appl. Sci. Res. 3:267-274.

Biale, J.B. and R.E. Young. 1971. The avocado pear, p. 1-63. In: Hulme, A.C. (ed.). The biochemistry of fruits and their products. Vol. 2. Academic Press, New York, NY.
Bruinsma, J. and R.E. Paull. 1984. Respiration during postharvest development of soursop fruit, Annona muricata L. Plant Physiol. 76:131-138.

Cruz-Castillo, J.G., O.A. Del Ángel-Coronel, J. De La Cruz-Medina, and M.C. Joaquín-Martínez. 2007. Características morfológicas y bioquímicas de frutos de chinene (Persea schiedeana Nees.). Rev. Chapingo Ser. Hort. 13:141-147.

Cutting, J.G.M. and B.N. Wolstenholme. 1991. Maturity effects on avocado postharvest physiology in fruits produced under cool environmental conditions. South African Avocado Growers' Association Yearbook 14:24-26.

Dixon, J., D. Smith, and T.A. Elmsly. 2004. Quality of avocado (Persea americana Mill.) fruit after storage in modified atmosphere Freshaway $^{\mathrm{TM}}$ bags. New Zealand Avocado Growers' Association Annual Research Report 4:80-85.

Gallina, S.S., S. Mandujano, and A. GonzalezRomero. 1996. Conservation of mammalian biodiversity in coffee plantations of Central Veracruz, Mexico. Agrofor. Syst. 33:13-27.

Gómez-López, V.M. 2002. Fruit characterization of high oil content avocado varieties. Scientia Agr. 59:403-406.

Hadfield, K.A., J.K.C. Rose, and A.B. Bennett 1995. The respiratory climacteric is present in Charentais (Cucumis melo cv. Reticulatus F1 Alpha) melons ripened on or off the plant. J. Expt. Bot. 46:1923-1925.

Jiang, Y.M. and J.R. Fu. 1999. Postharvest browning of litchi fruit by water loss and its prevention by controlled atmosphere storage at high relative humidity. Leben. Wissenschaft Tech. 32:278-283.

Joaquín-Martínez, M.C., J.G. Cruz-Castillo, J. De La Cruz-Medina, and O.A. Del Ángel-Coronel. 2007. Distribución ecogeográfica y características del fruto de Persea schiedeana Nees en Los Tuxtlas, Veracruz, México. Rev. Fitotecnia Mex. 30:403-410.

Kader, A.A. 2002. Postharvest biology and technology: An overview, p. 39-47. In: Kader, A.A (ed.). Postharvest technology of horticultural crops. Publication 3311. University of California Division of Agriculture and Natural Resources, Oakland, CA

Kader, A.A. and M.A. Arpaia. 2009. Avocado. Produce Facuss. Postharvest technology research and information center. 6 Sept. 2009. <http:// postharvest.ucdavis.edu/Produce/ProduceFacts/ Fruit/Avocado.shtml>.

Lavee, S. 1996. Biology and physiology of the olive, p. 59-110. In: International Olive Oil Council (IOOC) (eds.). The world olive encyclopedia. International Olive Oil Council, Madrid, Spain.

MacGuire, R.G. 1992. Reporting of objective color measurements. HortScience 27:1254-1255.

Munsell, H.E., L.O. Williams, L.P. Guild, C.B. Troescher, G. Nightingale, L.T. Kelley, and R.S. Harris. 1950. Composition of food plants of Central America. IV. El Salvador. J. Food Sci. 4:263-296.

Rendón-Cantillano, J.L. 2003. Caracterización física y química del fruto y del aceite de sucte (Persea schiedeana). Tesis de Ingeniero en Agroindustria. Escuela Agrícola Panamericana Zamorano, Francisco Morazán, Honduras, p. 21.

Saltveit, M.E., Jr. 1993. Carbon dioxide and ethylene levels in ripening tomato fruit attached to or detached from the plant. Physiol. Plant. 89:204-210.

Saltveit, M.E. and S.F. Yang. 1987. Ethylene, p. 367-401. In: Rivier, L. and A. Crozier (eds.). Principles and practices of plant hormone analysis. Vol. 2. Academic Press, New York, NY.

Shellie, K.C. and M.E. Saltveit. 1993. The lack of respiratory rise in musk melon fruit ripening on the plant challenges the definition of climacteric behavior. J. Expt. Bot. 44:1403-1406.

Tucker, G.A. 1993. Introduction, p. 1-52. In: Seymour, G.B., J.E. Taylor, and G.A. Tucker (eds.). Biochemistry of fruit ripening. Chapman and Hall, London, UK.

Zentmayer, G.A., E. Shieber, and F.B. Guillemet. 1988. History of the Martin Grande rootstock. Calif. Avocado Soc. Ybk. 72:121-125. 